Military Technical College

Kobry El-Kobbah,

Cairo, Egypt

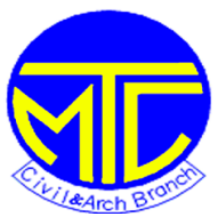

$12^{\text {th }}$ International Conference on Civil and Architecture Engineering

ICCAE-12-2018

\title{
Behavior of post and pre-heated RC short columns wrapped with ferrocement
}

\author{
Israa Abd Elhady ${ }^{1}$, Mahmoud Elsayed ${ }^{1}$, Alaa Elsayed ${ }^{*}$ \\ ${ }^{1}$ Department of Civil Engineering, Faculty of Engineering Fayoum University, Fayoum, Egypt \\ Corresponding author E-mail:alaa elsayed2009@yahoo.com
}

\begin{abstract}
In this work, experimental and numerical studies were carried out to investigate the behavior of pre- and post-heated RC short columns wrapped by ferrocement overlays. Ten RC columns were constructed and tested expermintally under axial load. The tested columns were divided into unheated columns, post-heated columns, post-heated columns repaired with ferrocement, and heated wrapped columns. All heated columns were heated at a temperature of $300^{\circ} \mathrm{C}$ for 3 hours. The experimental results were utilized for validation of the finite element models which developed by using ANSYS 13 software package. Based on the experimental and numerical results it is suggested that an equation that could predict the ultimate load of pst heated RC short columns wrapped by ferrocement. Afterwards, a wide range of the analysis was conducted models were analyzed to observe the effect of other parametric studies on the enhancement of axial load of post-heated columns confined by ferrocement. The results of the design equation were mutually compared with both the experimental and numerical ones. The research proved that the repairing scheme has an efficiency in surpassing the failure load of and improving the ultimate strength of heated columns significantly. The results of both the finite element and the prediction of the equation gave a satisfactory agreement with experimental ones.
\end{abstract}

Keywords: Strengthening, RC columns, Heat, Ferrocement, ANSYS

\section{Introduction}

Columns are considered one of the main structural elements within concrete structures. As they form the main support for other load bearing elements, e.g. beams and slabs. Their collapse during afire can be detrimental to the stability of the rest of the structure. Consequently, cracking and spalling of concrete columns after a fire exposure are often accompanied withthecorrosion of internal steel reinforcement. Furthermore, drastic reduction occurred in loadcarrying capacities of the columns after being exposedto fire. Inevitably, it is urgently needed to strengthen and rehabilitate suchcolumns. The most common and traditional techniques of repairing columns are to bond steel plates or enlargethe column cross-section usingconcrete jackets. However, there are other advanced methodsto strengthen and repaircolumns, such as FRP,which is an expensive technique that mandatescomplexapplicationprocedures. Ferrocement has been currently used 
tostrengthenconcrete elements as an alternativerepair material due to its ease of application as well as low cost.Ferrocement is a form of reinforcedconcrete thatis made of a single or multiple layers of wire mesh and/or small-diameter rods completely encapsulated in mortar[1]. Numerous experimental and numerical studies were performed to evaluate the performance of strengthening schemes on the behaviour of RC columns exposed to high temperatures. Significant studies have been investigated the influence of utilising ferrocement confinement in strengthening and repairingRCcolumns [2-11]. In general, the results indicated that the strength and deformability of RCcolumnscould be enhanced by encased ferrocement. Many studies [12-19]investigated experimentally the efficiency of using FRP, CFRP, and GFRP as strengthening techniquesto repairRCcolumnsexposed to different elevated temperature rates. The experimental results proved that wrapping RCcolumns with FRP scheme improve the ultimate load carrying capacities and enhance the ductility. Al-Kamakiet al. [20]carried outan experimental and numerical study on thebehaviour of heated RCcolumnsencased inCFRP. Also, El-Karmoty [21] carried out an experimental and theatrical study on the response ofthermal protection of RC retrofitted by GFRP overlays.Tettaand Dionysios [22] studied the performance of TRM and FRP wrapping in theshear strengthening of RC beams exposed to different levels of temperature. Yaqubet al. [23] carried out an experimental study to investigate the behaviour of post-heated RC columns enveloped with FRP composites. Yaqub and Bailey[24] and Bailey and Yaqub [25]studied experimentally the behaviour of post-heated RCsquare and circular columns wrapped with glass or carbon fibre reinforced polymers.Yaqub et al. [26] carried out an experimental investigation to evaluate the efficiency of using ferrocement and fibre reinforced FRP jackets for the repair of thepost-heated square and circular reinforced concrete columns.

\section{Research significance}

The aim of this work is toinvestigate the efficiency of using ferrocement confinement in repairing heated $\mathrm{RC}$ columns. In order to do that, ten RC columns were tested experimentally. The phases of laboratory program included columns which were unheated, post-heated, repaired post-heated with ferrocement jacket and wrapped columns with ferrocement subsequent heated (pre-heated). Then, numerical analysis and predicted formula were performed to determine the ultimate load carrying capacities of tested columns.Finally, nonlinear finite element models were developed to cover other parameters which were not studied experimentally.

\section{ExperimentalProgram \\ 4.1 MaterialProperties}

The same batch of theconcretemix was used for all columns to preserve the same strength of concrete. The concrete mixing compositions were $350 \mathrm{~kg} / \mathrm{m}^{3}$ cement, $170 \mathrm{~kg} / \mathrm{m}^{3}$ free water, $650 \mathrm{~kg} / \mathrm{m}^{3}$ fine aggregate, and $1170 \mathrm{~kg} / \mathrm{m}^{3}$ coarse aggregate. The average compressive strength of concrete was $27 \mathrm{MPa}$ at 28 days. The proportion of the ferrocement mortar mixes was 1:0.4:2 of the cement, water, and sand, respectively. A total of $1.5 \%$ super plasticizer and $15 \%$ of silica-fume by weight of cement were added to improve the workability and the strength of the matrix.The average mortar grade at the time of testing was $37 \mathrm{MPa}$.The mix ratio for concrete was1:0.48:1.28:2.17 of cement, water, fine and coarse aggregate, respectively. The average compressive strength of concrete was $27 \mathrm{MPa}$ at 28 days. The ratio of the mortar mixture was 1:0.4:2 of the cement, water, and sand, respectively. A total of $1.5 \%$ super plasticizer and $15 \%$ of silica-fume by weight of cement were added to improve the workability and the strength of the matrix. The average mortar strengthwas $35 \mathrm{MPa}$ at 28 days. 
Three different types of reinforcing steel bars were used as shown inTable 1. Expanded wire mesh(diamond) was used as a ferrocement reinforcement jacket.The diameterof wires in the mesh was $1.35 \mathrm{~mm}$ anddiameter $28 \mathrm{mmX} 16 \mathrm{~mm}$ wire spacing. The yield strength and modulus of elasticity of individual wires of the mesh were $370 \mathrm{MPa}$ and $175000 \mathrm{MPa}$ respectively.

Table 1:Properties of steel reinforcement.

\begin{tabular}{|cccccc|}
\hline Bar name & $\begin{array}{c}\text { Actual } \\
\text { Diameter } \\
(\mathrm{mm})\end{array}$ & $\begin{array}{c}\text { Actual area } \\
(\mathrm{mm} 2)\end{array}$ & $\begin{array}{c}\text { Yield Strength } \\
(\mathrm{MPa})\end{array}$ & $\begin{array}{c}\text { Ultimate } \\
\text { Strength } \\
(\mathrm{MPa})\end{array}$ & $\begin{array}{c}\text { Young's } \\
\text { Modulus (MPa) }\end{array}$ \\
\hline$\varnothing 6 \mathrm{~mm}$ & 6 & 28.3 & 282 & 459 & 195000 \\
$\Phi 10 \mathrm{~mm}$ & 9.91 & 77.1 & 412 & 628 & 195000 \\
$\Phi 16 \mathrm{~mm}$ & 15.85 & 197.2 & 412 & 628 & 195000 \\
\hline
\end{tabular}

\section{Test Specimens}

In order to evaluate the efficiency of applying ferrocement overlays in repaired RC columns exposed to fire, ten RC columns were constructed and tested experimentally. The schematic experimental layout consists of the cast and cure the RC columns, heated them to temperature, wrap them with ferrocement and then test the specimens under axial load. All the specimens have the same square cross-section of $150 \mathrm{~mm}$ and a height equivalent to a $1000 \mathrm{~mm}$. The specimens were equally divided into two groups, of five columns each, based on the longitudinal reinforcement. The first group have $4 \Phi 10 \mathrm{~mm}$ and second one have $8 \Phi 16 \mathrm{~mm}$ which corresponds to a longitudinal reinforcement ratio was $1.3 \%$ and $7 \%$, respectively. All columns have the same number and arrangement of stirrups. The columns geometry, reinforcement, and properties of the control, as well as the confined columns, are plotted in Fig. 1. The specimens were tested under four different conditions described in the sequel:

(a) Two unheatedcolumns without ferrocement jacket;

(b) Twoheated columns without repairing;

(c) Twowrappedcolumns with heating;

(d) Fourheated and repaired columnswith ferrocementjacket. 


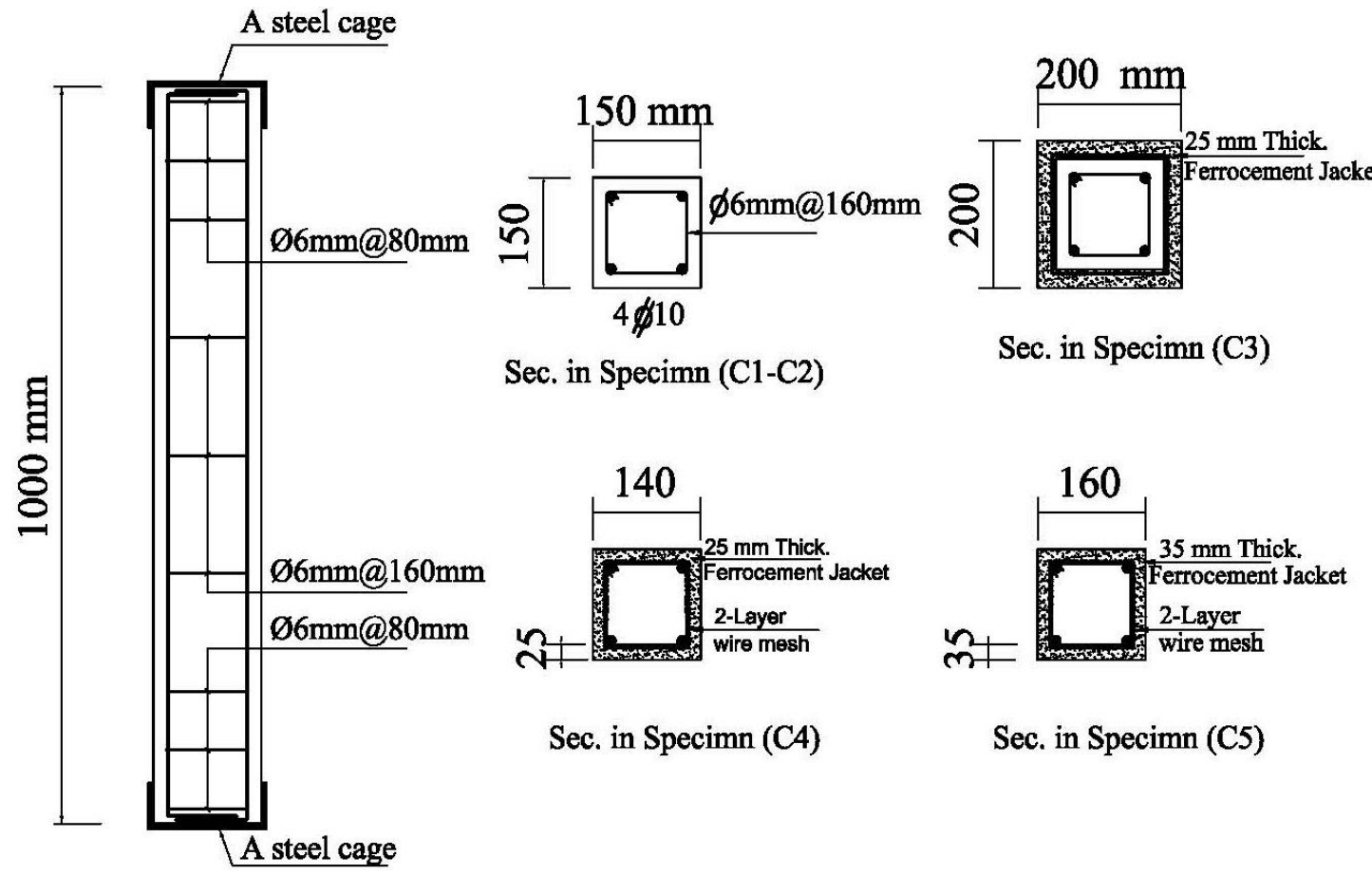

Longitudinal of non-Jacketed column

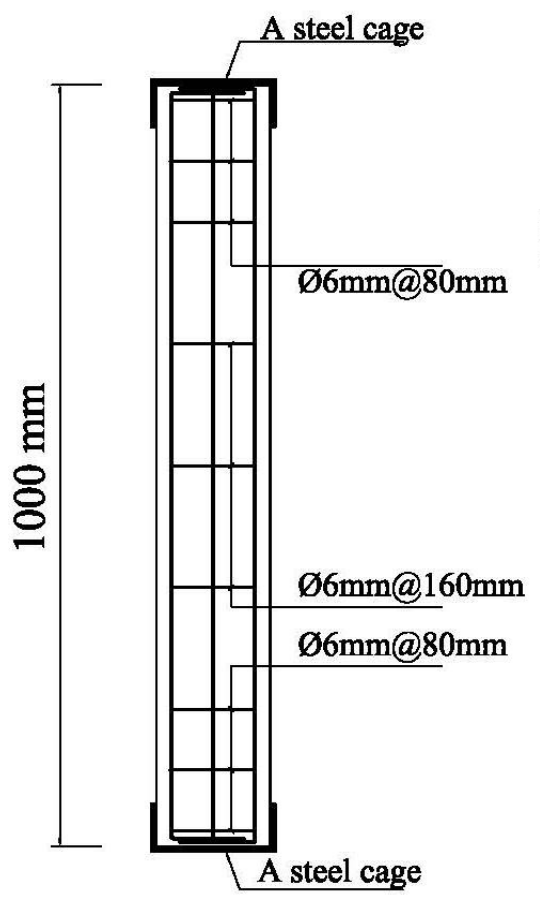

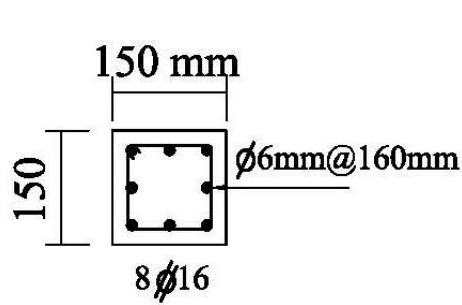

Sec. in Specimn (C6-C7)

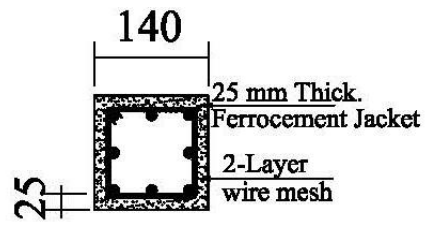

Sec. in Specimn (C9)

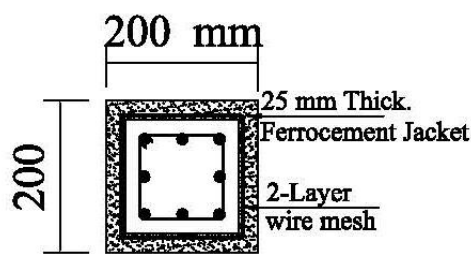

Sec. in Specimn (C8)

Longitudinal of non-Jacketed column

b) Column specimens Details for Group 2 .

Fig. 1: Columns designations, dimensions and reinforcement arrangement.

For the heated specimens, all columns were heated to a uniform temperature of $300{ }^{\circ} \mathrm{C}$ for 3 hours before allowing to cool down. Table 2gives the descriptions and parametric studies for all tested columns. 
Table 2: Specimen nomination.

\begin{tabular}{|c|c|c|c|c|c|}
\hline Group & $\begin{array}{l}\bar{D} \\
\stackrel{\Xi}{0} \\
\mathbb{D} \\
\tilde{D}\end{array}$ & Column condition & 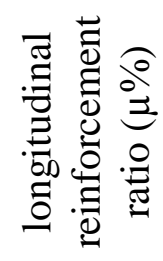 & 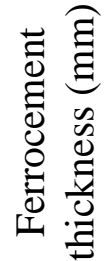 & $\begin{array}{c}\text { No of } \\
\text { wire } \\
\text { mesh }\end{array}$ \\
\hline \multirow{5}{*}{ 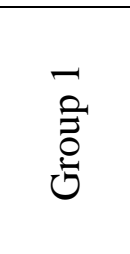 } & $\mathrm{C} 1$ & Unheated/non-jacketed & \multirow{5}{*}{1.3} & $\begin{array}{c}--- \\
\end{array}$ & $-\overline{----}$ \\
\hline & $\mathrm{C} 2$ & Post-heated/non-jacketed & & ---- & ---- \\
\hline & $\mathrm{C} 3$ & Ferrocementconfinement/ Pre-heated & & 25 & 2 \\
\hline & $\mathrm{C} 4$ & Post-heated/Ferrocement repaired & & 25 & 2 \\
\hline & C5 & Post-heated/Ferrocement repaired & & 35 & 2 \\
\hline \multirow{5}{*}{ 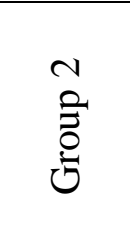 } & C6 & Unheated/non-jacketed & \multirow{5}{*}{7} & ---- & ---- \\
\hline & $\mathrm{C} 7$ & Post-heated/non-jacketed & & ---- & ---- \\
\hline & $\mathrm{C} 8$ & Ferrocementconfinement/ Pre-heated & & 25 & 2 \\
\hline & C9 & Post-heated/Ferrocement repaired & & 25 & 2 \\
\hline & $\mathrm{C} 10$ & Post-heated/Ferrocement repaired & & 35 & 2 \\
\hline
\end{tabular}

\subsection{Test procedures,Instrumentation and Test Setup}

After casting and curing the column specimens, the testing procedure has been executed according to the following steps as shown in Fig. 2.

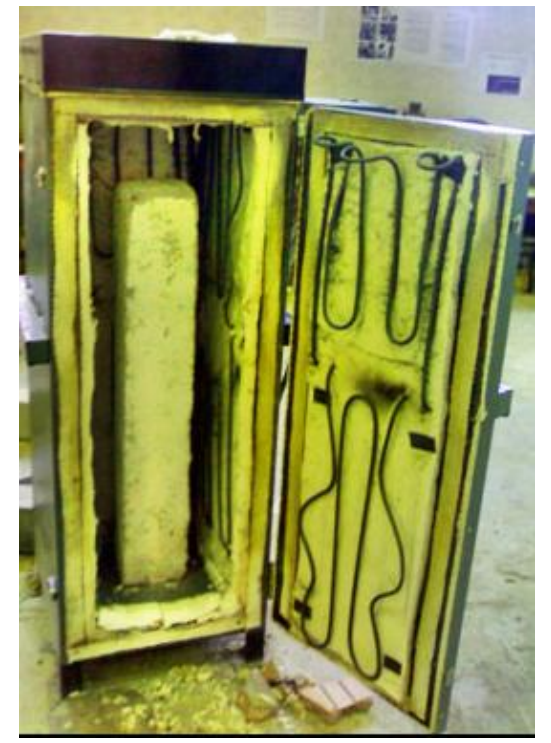

a)Column in electric furnace

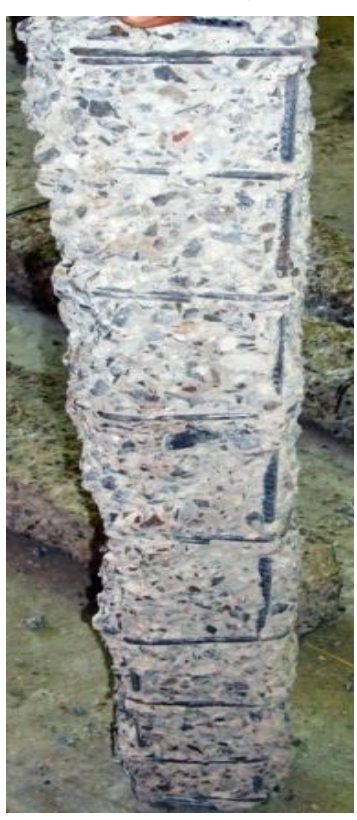

b)Columns after removing the concrete cover

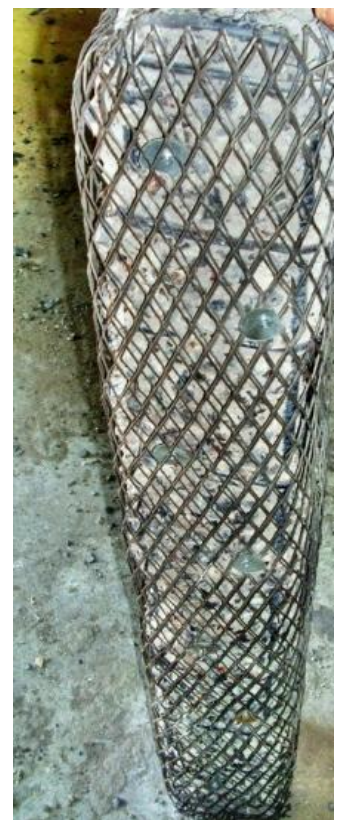

c)Wrapping the wire mesh around the column

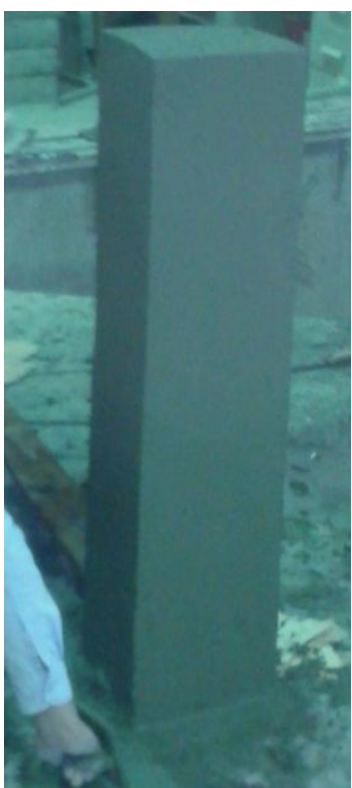

d)applying ferrocement jacket

Fig. 2: Stages of preparing ferrocement jacket.

- Stage one;the column specimens (C2, C4, C5, C7, C9, and C10) were heatedin anelectric furnace to a temperature of $300^{\circ} \mathrm{C}$ for 3 hours. 
- Stage two; repairing of damaged heat columns with ferrocement. Prior to applying the ferrocement, the cover of the heated columns wasremoved and cleaned to get rid of the dust.The required wire meshes were cut and wrapped around the entire column.Then the primer bonding mortar was plastered on column sides to give high adhesion between the concrete core of the column and the next layer (Matrix). Finally applying the mortar layer.

- Stage three;theconfined columns (C3 and C8) were heatedin anelectric furnace to a temperature of $300^{\circ} \mathrm{C}$ for 3 hours.

- Step four;allspecimenswere tested under concentric loading mode. Before testing all columns were fixed by using a steel cage connected to the upper and lower ends of each columnin order to avoid stress concentration problems and to ensure distribution the load uniformly.Thecompressive load was applied using a $1000 \mathrm{kN}$ capacity hydraulic jack in a monotonically increasing manner. The details of the test setup are shown inFig. 3.

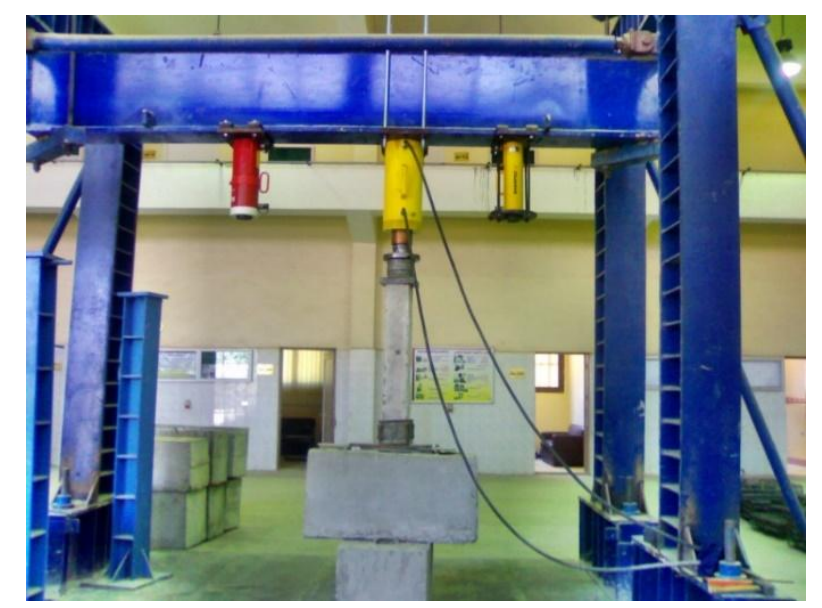

Fig. 3: Loading frame and test set up.

\section{Numerical analysis using finite element implementation}

All tested columns were simulated using the finite element package ANSYS 13 [27]in order to compare the experimental results with the numerical ones. The results of the experimental work were used to confirmthe finite element models.

\subsection{Defining material properties}

The current simulation model takes into consideration both the geometry and non-linearity of the material. In this study, the solid65 element was used to simulatethe concrete and the mortar. The solid65 element is defined by eight nodes, where each node has three degrees of freedom (translations in the $\mathrm{X}, \mathrm{Y}$, and $\mathrm{Z}$ directions). This element has cracking and crushing capabilities. Fig. 4 presents node`s locations and the coordinate system of SOLID65. On the one hand, the Link- 8 , a 3D link element, is used to modelling the transverse and the longitudinal reinforcement. While the 3D Solid-45 element is used to represent the reinforced concrete solid element as well as modelling the steel wire mesh. Table 3 shows the properties for each element. 


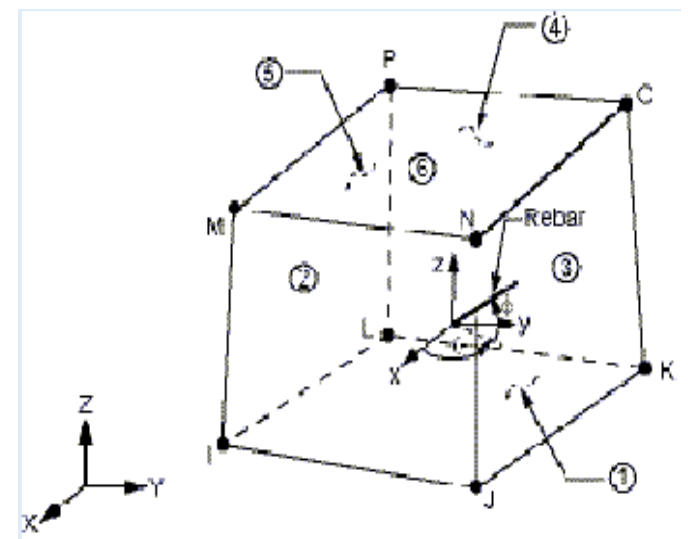

Fig. 4: Node locations and thecoordinate system of solid65.

Table 3: Material properties for each element.

\begin{tabular}{|c|c|c|c|}
\hline Material & Element type & Material properties & \\
\hline \multirow{6}{*}{ Concrete } & \multirow{6}{*}{ Solid 65} & Elastic modulus (Ex) & $4400 \sqrt{f} c u \mathrm{MPa}$ \\
\hline & & Uniaxial crushing stress ( $\mathrm{fc}^{\prime}$ ) & fcuMPa \\
\hline & & Uniaxial tensile stress (ft) & $0.6 \sqrt{f c u \mathrm{MPa}}$ \\
\hline & & Poisson's ratio (v) & 0.20 \\
\hline & & Shear coefficient for open shear $(ß t)$ & 0.20 \\
\hline & & $\begin{array}{l}\text { Shear coefficient for closed shear } \\
(ß c)\end{array}$ & 0.85 \\
\hline \multirow{4}{*}{$\begin{array}{l}\text { Longitudinal } \\
\text { reinforcement }\end{array}$} & \multirow{4}{*}{ Link 8} & Elastic modulus (Ex) & $195000 \mathrm{MPa}$ \\
\hline & & Yield stress (fy) & $412 \mathrm{MPa}$ \\
\hline & & Tensile Strength & $628 \mathrm{MPa}$ \\
\hline & & Poisson's ratio $(v)$ & 0.30 \\
\hline \multirow{4}{*}{ Stirrups } & \multirow{4}{*}{ Link 8} & Elastic modulus (Ex) & $200000 \mathrm{MPa}$ \\
\hline & & Yield stress (fy) & $282 \mathrm{MPa}$ \\
\hline & & Tensile Strength & $459 \mathrm{MPa}$ \\
\hline & & Poisson's ratio (v) & 0.30 \\
\hline \multirow{6}{*}{ Mortar } & \multirow{6}{*}{ Solid 65} & Elastic modulus (Ex) & $24100 \mathrm{MPa}$ \\
\hline & & Uniaxial crushing stress (fcu) & $35 \mathrm{MPa}$ \\
\hline & & Uniaxial tensile stress (ft) & $3.60 \mathrm{MPa}$ \\
\hline & & Poisson's ratio $(v)$ & 0.20 \\
\hline & & Shear coefficient for open shear $(ß t)$ & 0.02 \\
\hline & & $\begin{array}{l}\text { Shear coefficient for closed shear } \\
(ß c)\end{array}$ & 0.4 \\
\hline \multirow{4}{*}{ Wire Mesh } & \multirow{4}{*}{ Solid 45} & longitudinal Elastic modulus & $175000 \mathrm{MPa}$ \\
\hline & & Yield stress (fy) & $370 \mathrm{MPa}$ \\
\hline & & Poisson's ratio (v) & 0.30 \\
\hline & & Thickness & $1.35 \mathrm{~mm}$ \\
\hline
\end{tabular}




\section{Numerical Modelling of Columns}

Fig. 5shows ANSYS numerical model representation of the experimental specimens. In order to gain accurate results, the full height of the columnsis considered for the creation of the models with amesh size equivalent to $50 \mathrm{~mm}$.

\subsection{Boundary conditions and Loading Scheme}

The experiment conditions have been used to define the boundary conditions while the load application of the finite element analysis has been described to simulate the actual loading sequence. The columns were modelled in thevertical direction, where the horizontal translations of all base joints were restrained in the three directions. In a nonlinear environment, a displacement control incrementally increasing loading was monotonically appliedon the top faceof the column.

\section{The Prediction Equation}

In order to predict the ultimate failure load of unwrapped and wrapped heated columns by ferrocement, the following prediction equation was suggested.

$$
P_{u f}=0.65 f_{c u}\left(A_{c}-A_{s t}\right)+f_{y} A_{s t}+0.65 f_{c u f} A_{c f}+A_{s f} f_{y f}
$$

$\mathrm{P}_{\mathrm{uf}}$ : Ultimate Failure Load

Ac: Gross area of the core of concrete

$f_{y}$ : Yield strength of steel

$\mathrm{A}_{\mathrm{st}}$ : Area of longitudinal steel

$\mathrm{A}_{\mathrm{sf}}$ : Area of steel wire mesh $\mathrm{f}_{\text {cu }}$ : Compressive strength of concrete after heating $\mathrm{f}_{\text {cuf: }}$ : Compressive strength of cement mortar

$\mathrm{A}_{\mathrm{cf}}$ : Area of cement mortar

$\mathrm{f}_{\mathrm{yf}}$ :Yield strength of wire mesh

This equation was expected to give an estimate failure loads for other values of thevolume fraction of reinforcement, values of ferrocement thickness, and mortar grade.

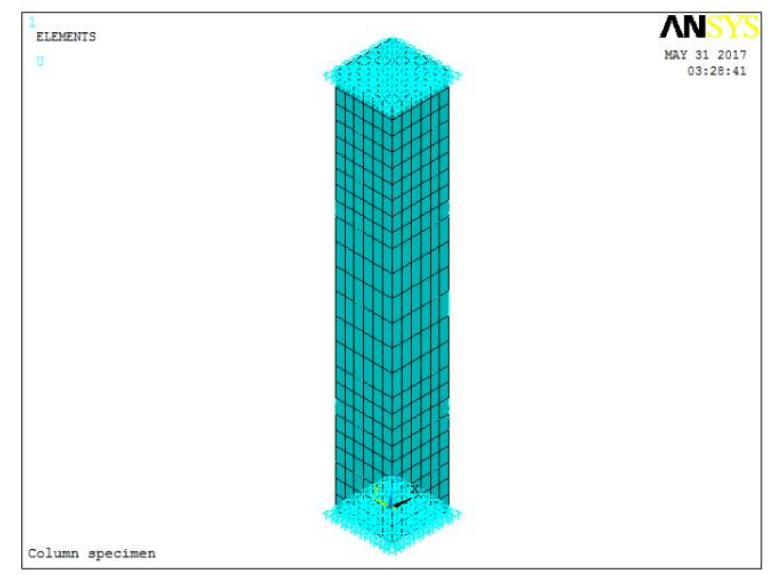

Fig. 5: ANSYS numerical model.

\section{Results and Discussion}

\subsection{Experiment Results}


The main results ofthis experimental program to be discussed are the ultimate load carrying capacity, the crack propagation and mode of failure of the tested specimens.

\subsubsection{Ultimate Failure Load}

All columns were tested until they reached their failure load. The failure loads of the first and second group are plotted in Fig. 6 and Fig. 7, respectively. Furthermore; Table 4 summarizes all the test results. It can be shown that after heating, the failure load of columns was reduced significantly. However, a considerable load was restored after wrapping heated columns by ferrocement. The ultimate load carrying capacities of under and over reinforced columns were reduced by up to $45 \%$ and $33 \%$ respectively after heating. It can be seen that the axial ultimate load of heated confined columns was reduced by $13 \%$ and $8 \%$ for both under and over reinforced columns respectively. The results indicated that repairing post-heated columns, caused $63 \%$ and $41 \%$ increase in ultimate load for under and over reinforced columns respectively. In the case of confined pre-heated columns, it can be seen that ferrocement strengthening technique was influential in protecting the columns. The decrease in failure load of the post-heated over reinforced columns is less than under reinforced columns.

Table 4: Summary of the test results of specimens.

\begin{tabular}{|c|c|c|c|c|c|c|}
\hline $\begin{array}{l}\text { Oे } \\
\text { ல் }\end{array}$ & $\begin{array}{c}\text { No. of } \\
\text { specime } \\
n\end{array}$ & $\begin{array}{l}\text { Compressive } \\
\text { strength of } \\
\text { heated } \\
\text { column }\end{array}$ & $\begin{array}{c}\% \text { Losses in } \\
\text { compressive } \\
\text { strength }\end{array}$ & $\begin{array}{l}\text { Failure } \\
\text { Load } \\
(\mathrm{kN})\end{array}$ & $\begin{array}{l}\text { \% Increase in } \\
\text { the column } \\
\text { failure load } \\
\text { above heated } \\
\text { column }\end{array}$ & $\begin{array}{c}\text { \% Reduction } \\
\text { in the column } \\
\text { Failure Load } \\
\text { compared } \\
\text { with unheated } \\
\text { column }\end{array}$ \\
\hline \multirow{5}{*}{ 官 } & C1 & 27 & 0.0 & 543 & 82.2 & 0.0 \\
\hline & $\mathrm{C} 2$ & 12 & 56 & 298 & 0.0 & 45.1 \\
\hline & C3 & 25 & 7.5 & 472 & 58.4 & 13.1 \\
\hline & $\mathrm{C} 4$ & 12 & 56 & 429 & 44.0 & 21.0 \\
\hline & C5 & 12 & 56 & 485 & 62.8 & 10.7 \\
\hline \multirow{5}{*}{ 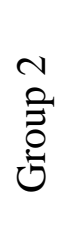 } & C6 & 27 & 0.0 & 917 & 49.8 & 0.0 \\
\hline & C7 & 12 & 56 & 612 & 0.0 & 33.3 \\
\hline & C8 & 25 & 7.5 & 846 & 38.2 & 7.7 \\
\hline & C9 & 12 & 56 & 795 & 29.9 & 13.3 \\
\hline & $\mathrm{C} 10$ & 12 & 56 & 861 & 40.7 & 6.1 \\
\hline
\end{tabular}




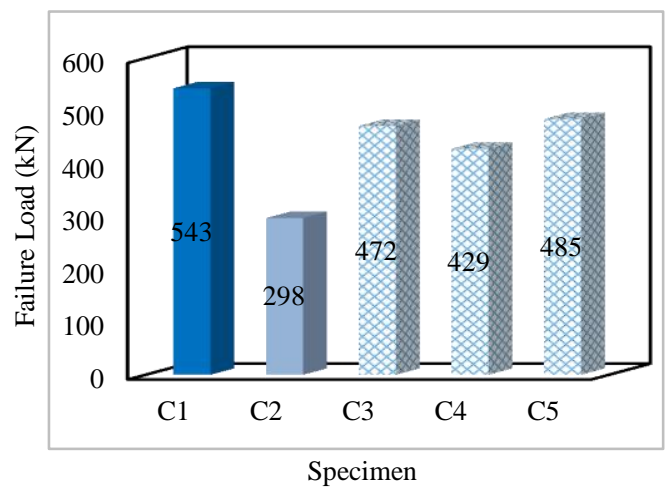

Fig. 6: Failure load of columns for group 1.

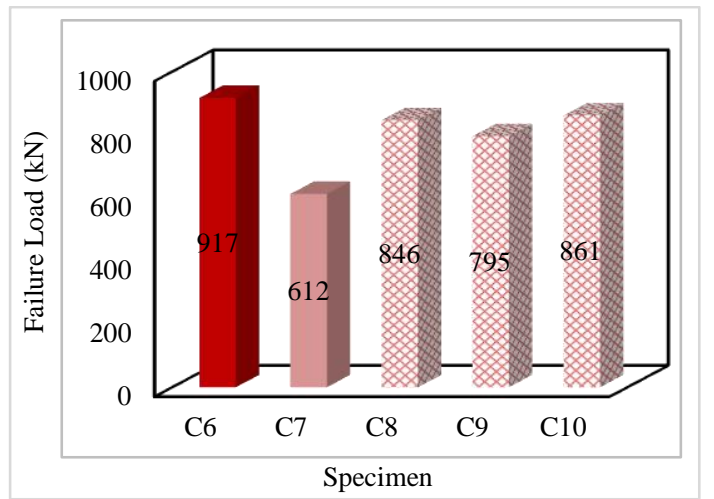

Fig. 7: Failure load of columns for group 2.

\subsubsection{Failure Modes and Cracking Patterns}

The surface of the columns was carefully observed following heating. Random small cracks on the surface of each column were observed. Fig. 8 shows the damages observed at failure load. Generally, a typical crushing mode of failure was observed for all the tested specimens. The most tested columns were failed at their end or ends due to the effects of accumulation and concentration of stresses in such regions. As the load increases, inclined cracks started to appear near the bottom of the column head, increasing in number and getting wider in aperture until failure occurs suddenly. Also, it can be seen that the failure occurs due to the collapse of concrete strength at the lower part of columns. For post-heated repaired columns, the failure was initiated by vertical hairline cracks in the mortar of ferrocement due to the failure of wire mesh throughout the height of the column specimens. A segment of ferrocement mortar of pre-heated confinement columns was separated after heating in an electric furnace.

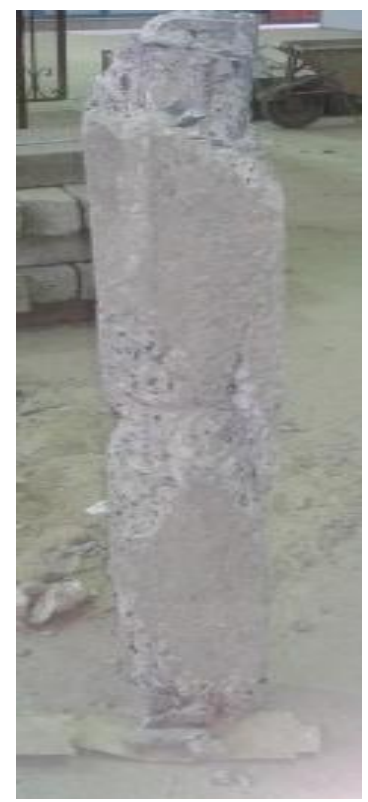

Failure mode for $\mathrm{C} 1$

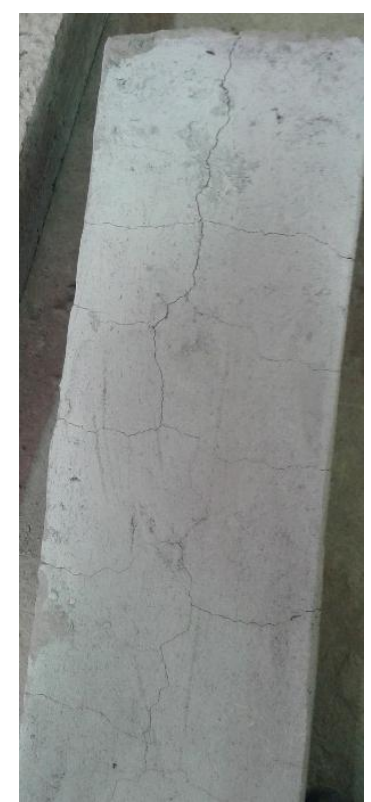

Cracks Appeared in post-heated column C2
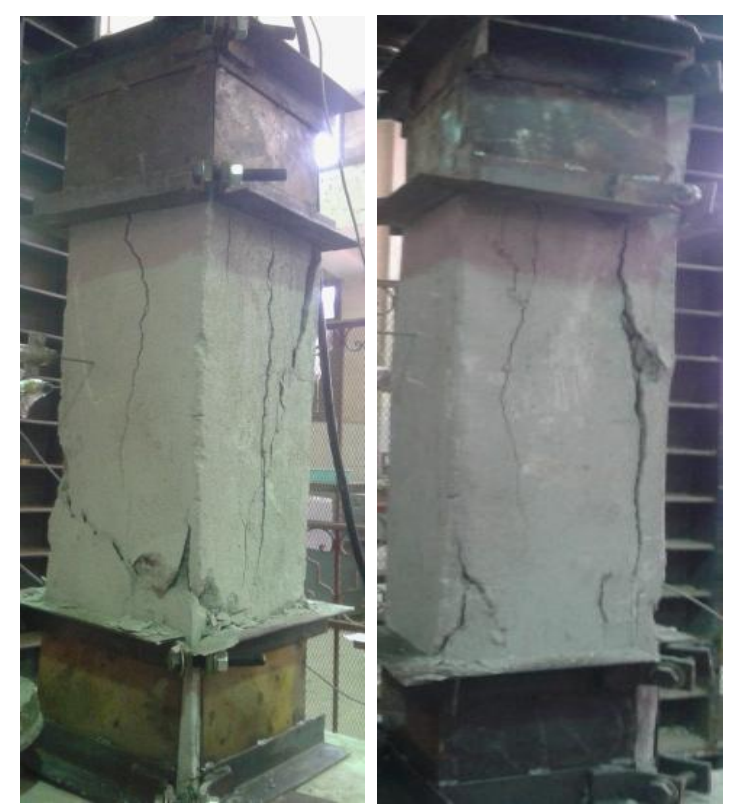

Failure mode for C4

Failure mode for C5 


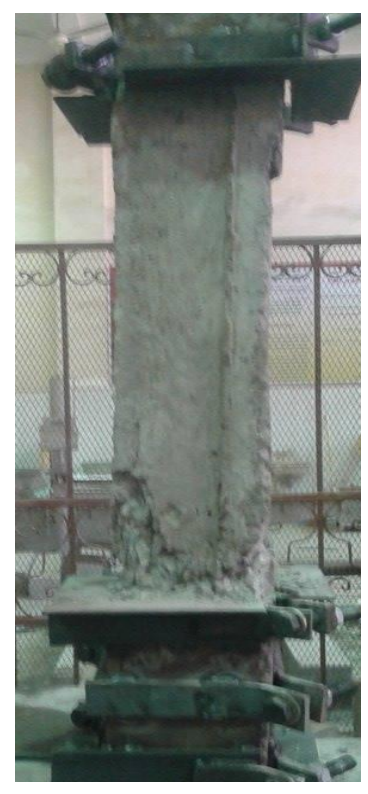

Failure mode for C6

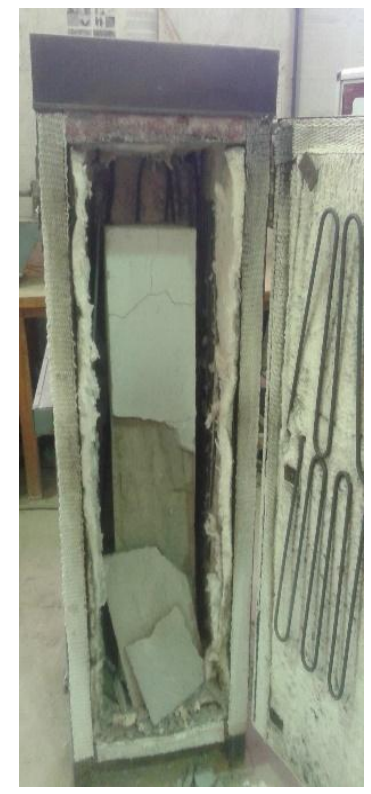

Separate of ferrocement mortar for pre-heated column C8
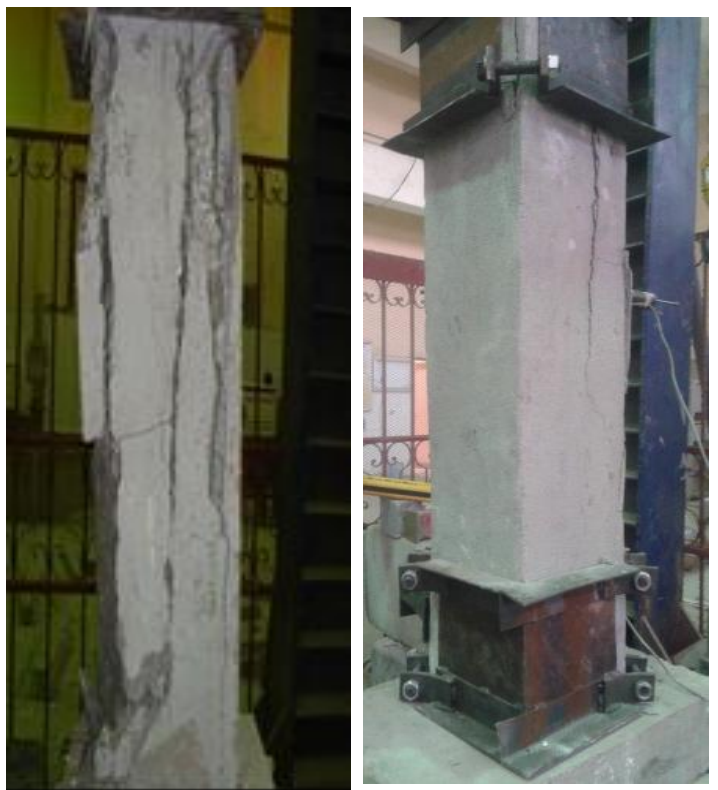

Failure mode for C8

Failure mode for C10

Fig. 8: Failure mode for tested specimens.

\section{Numerical Results}

\subsection{Failure Modes}

The deformed shapes for the tested specimens and the concrete cracks at failure load are plotted in Fig. 9. It observedthat the unwrapped columns have large deformations in concrete while cracked/crushed concrete elements were located in the near area of the column head with less concentration near the middle of the column`s height. It can also be noticed that post-heated columns failed in the middle zones. In all models; cracks started to develop in elements just located under the loading plates and they increased in quantity and width with the increasing load.

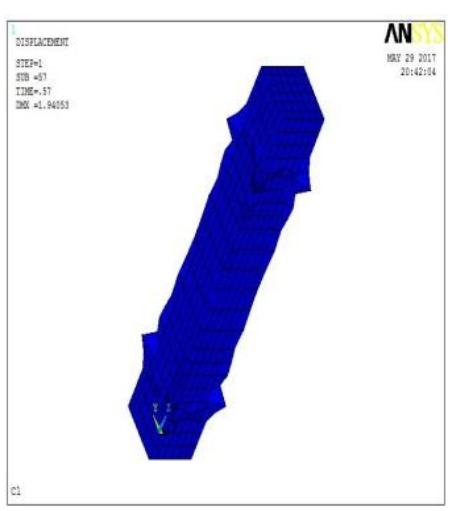

Column C1

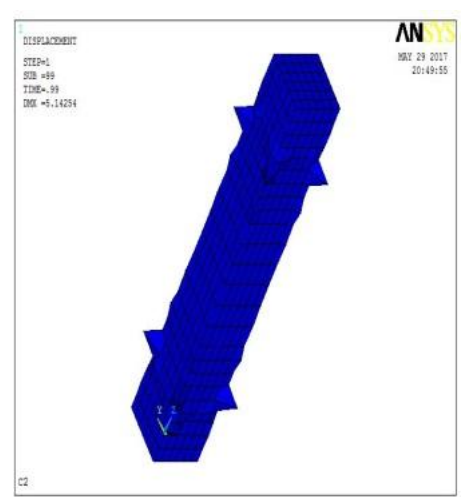

Column C2

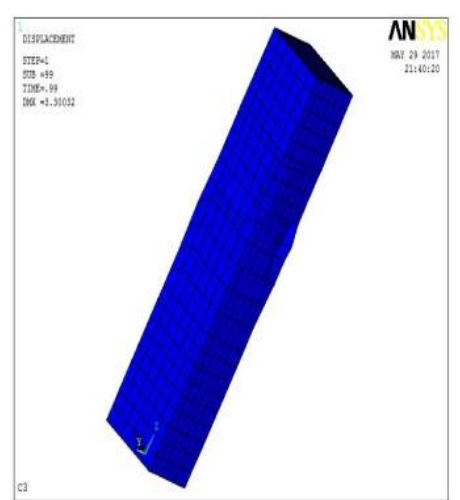

Column C3 


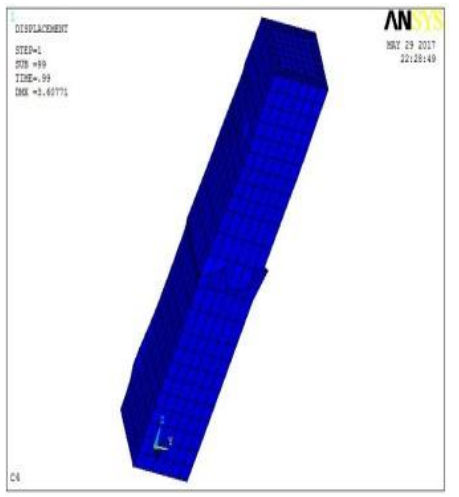

Column C4

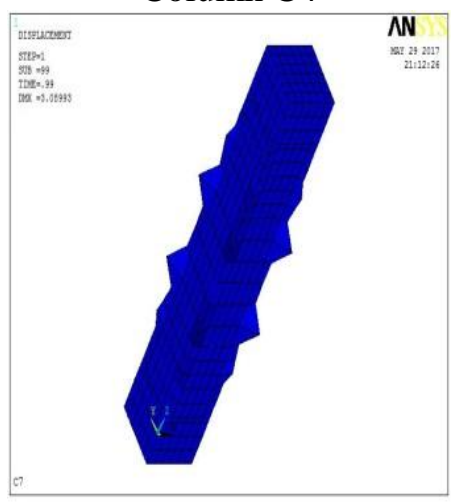

Column C7

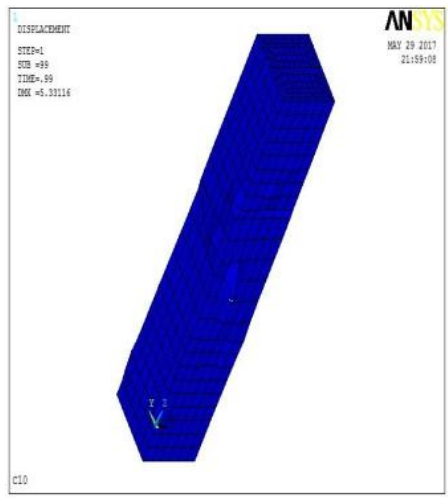

Column C10

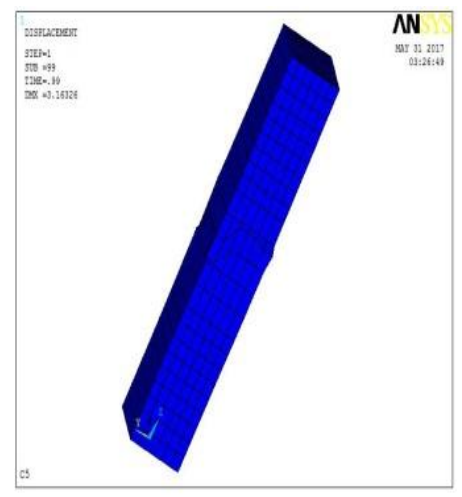

Column C5

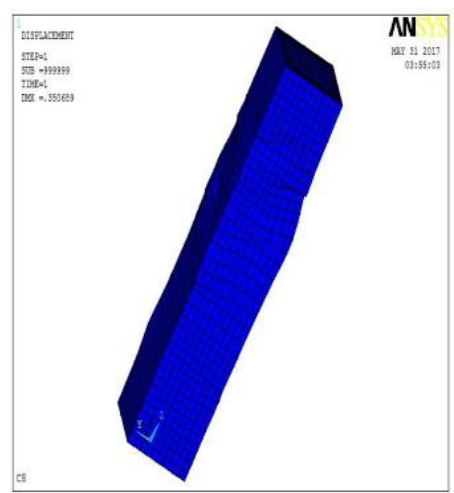

Column C8

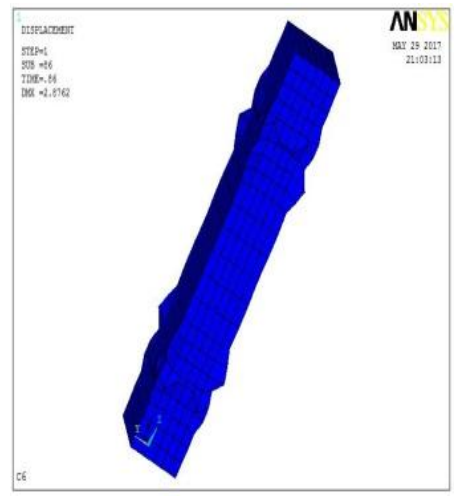

Column C6

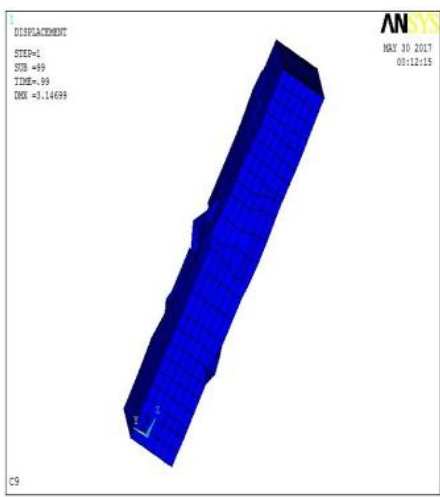

Column C9

Fig. 9:Deformation of all models at failure load.

\section{Compassion Between Experimental, Numerical and Prediction Equation Results}

Fig. 10 shows a comparison between experimental, numerical, and prediction design equation results for group1 and group 2. The ultimate failure loads of experimental, numerical, and prediction design equation results with the ratios between them are tabulated inTable 5 . The obtained numerical and prediction formulaultimate loads agrees quite well with the experimental ones, although the results slightly overestimate the failure load. In general,the experimental results show higher failure loads for most of the specimens compared to their corresponding finite element models. The maximum errors between experimental and the numerical resultsare $\pm 5 \%$ and the mean value of the ratio between them was 1.013 with a standard deviation 0.025 .It can be noticed that the predicted formula gave higher failure load values in comparison to the experimental values except for specimens $\mathrm{C} 1$ and $\mathrm{C} 4$. The average value of the ratio between experimental and design equation was $97 \%$ with standard 
deviation 0.046. It can be concluded thatthe results of finite element analyses are as accurate as those of theproposed formula, with respect to the ultimate load capacity. Finally, from the observation, the finite element program ANSYS is a useful and useable tool to determine the ultimate load capacity of unwrapped or wrapped heated or un-heated columns.

Table 5: Compression between experimental, numerical and prediction equation results.

\begin{tabular}{|c|c|c|c|c|c|}
\hline \multirow{2}{*}{$\begin{array}{l}\text { Column } \\
\text { Specimen }\end{array}$} & \multicolumn{3}{|c|}{ Failure Load $(\mathrm{kN})$} & \multirow{2}{*}{$\frac{E X P .}{A N S Y S}$} & \multirow{2}{*}{$\frac{E X P .}{E q u .}$} \\
\hline & Exp. & ANSYS & Equ. & & \\
\hline $\mathrm{C} 1$ & 543 & 538 & 521 & 1.01 & 1.04 \\
\hline $\mathrm{C} 2$ & 298 & 283 & 286 & 1.05 & 1.04 \\
\hline $\mathrm{C} 3$ & 472 & 488 & 485 & 0.97 & 0.97 \\
\hline $\mathrm{C} 4$ & 429 & 421 & 412 & 1.02 & 1.04 \\
\hline $\mathrm{C} 5$ & 485 & 502 & 489 & 0.97 & 0.99 \\
\hline C6 & 917 & 886 & 987 & 1.03 & 0.93 \\
\hline $\mathrm{C} 7$ & 612 & 598 & 641 & 1.02 & 0.95 \\
\hline $\mathrm{C} 8$ & 846 & 838 & 923 & 1.01 & 0.92 \\
\hline C9 & 795 & 789 & 833 & 1.01 & 0.95 \\
\hline \multirow[t]{3}{*}{$\mathrm{C} 10$} & 861 & 830 & 891 & 1.04 & 0.97 \\
\hline & & \multicolumn{2}{|c|}{ Average } & 1.013 & 1.077 \\
\hline & & \multicolumn{2}{|c|}{ Standard deviation } & 0.025 & 0.046 \\
\hline
\end{tabular}
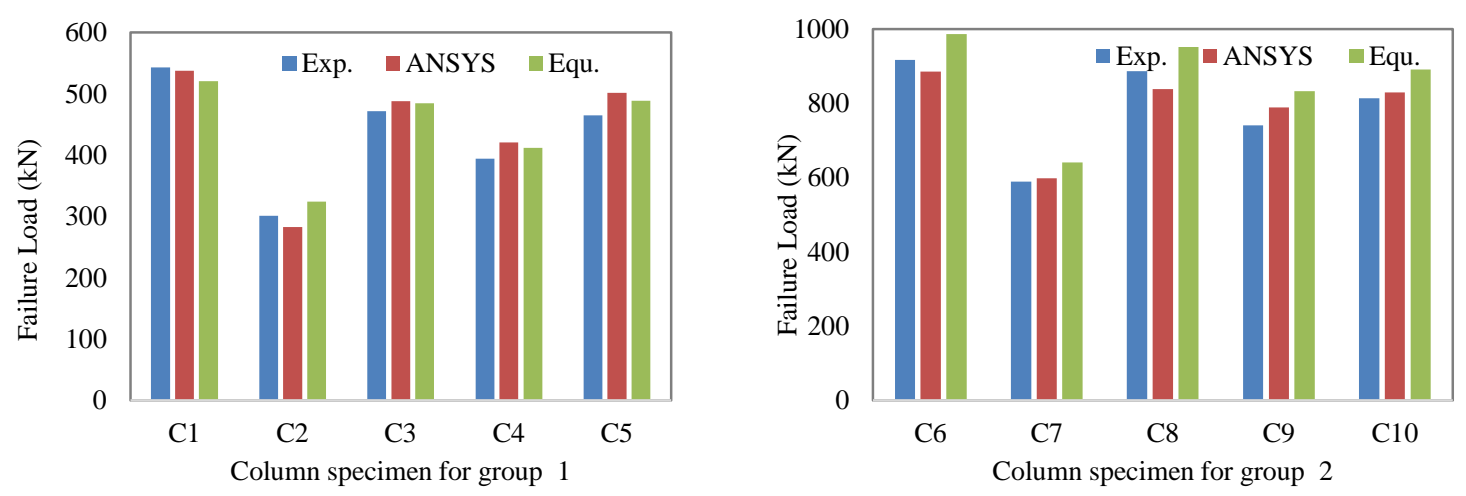

Fig. 10: Compression between experimental, numerical and Prediction Equation results.

\section{Parametric study}

\subsection{Numerical Models Discerption}

The finite element model was used to extend the parametric study to cover other parameters which have not been investigated experimentally. A total of 60 extra models were analyzed to investigate the efficiency of using ferrocement laminates inrepairingpost-heated RC columns. The studied parameters were, the ferrocement thickness, mortar grade, the number of steel wire mesh, and the main reinforcement ratio. Five different thicknesses of ferrocement were taken into account $(10 \mathrm{~mm}, 15 \mathrm{~mm}, 20 \mathrm{~mm}, 25 \mathrm{~mm}$, and $30 \mathrm{~mm})$. The considered mortar strength were $60 \mathrm{MPa}$ and $90 \mathrm{MPa}$. The number of weld mesh layerswere considered with three different values: (1,2, and 3 layers).The longitudinal reinforcement was considered with 
three different values: $(4 \Phi 10,8 \Phi 16)$. The description of the additional column models are given in Table6.

\subsection{Parametric Study Results}

Table6 shows the failure loads of the finite element models.On the basis of the numerical results, ferrocement jackets can be used to improve the load carrying capacity of the heated $\mathrm{RC}$ columns. The results clearly showed that ferrocement confinement leads to a significant enhancements in the failure loads of the confined columns. The strength of the post-heated wrapped columns is significantly affected by both the ferrocement thickness and mortar strength. It can be seen that increasing the percentage volume of the wire mesh layer subsequently increasing the ultimate load of the columns.It can be noticed that the strength of the heated column withthree weld mesh layersgreater compared to with that of two layers for the same thickness of slab.

Table 6: The description of the additional column models and results.

\begin{tabular}{|c|c|c|c|c|c|c|c|}
\hline Model & $\begin{array}{l}\text { Main } \\
\text { RFT. }\end{array}$ & 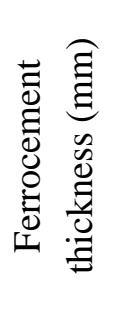 & $\begin{array}{l}\text { No of } \\
\text { wire } \\
\text { mesh }\end{array}$ & 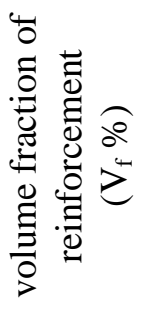 & 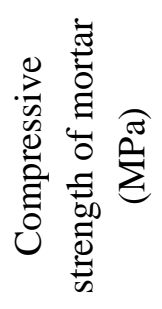 & $\begin{array}{c}\text { Failure } \\
\text { Load }(\mathrm{kN})\end{array}$ & $\begin{array}{l}\% \text { Increase in the } \\
\text { column failure } \\
\text { load above heated } \\
\text { column }\end{array}$ \\
\hline $\mathrm{Co}$ & $4 \Phi 10$ & \multicolumn{4}{|c|}{ Post-heated/non-jacketed (C2) } & 283 & 0.0 \\
\hline $\mathrm{C} 1$ & $4 \Phi 10$ & 10 & 1 & 1.86 & 65 & 337 & 19.1 \\
\hline $\mathrm{C} 2$ & $4 \Phi 10$ & 15 & 1 & 1.24 & 65 & 450.2 & 59.1 \\
\hline C3 & $4 \Phi 10$ & 20 & 1 & 0.93 & 65 & 568.5 & 100.9 \\
\hline $\mathrm{C} 4$ & $4 \Phi 10$ & 25 & 1 & 0.74 & 65 & 696.9 & 146.3 \\
\hline C5 & $4 \Phi 10$ & 30 & 1 & 0.62 & 65 & 819.1 & 189.4 \\
\hline C6 & $4 \Phi 10$ & 10 & 2 & 3.72 & 65 & 365.4 & 29.1 \\
\hline $\mathrm{C} 7$ & $4 \Phi 10$ & 15 & 2 & 2.48 & 65 & 463 & 63.6 \\
\hline $\mathrm{C} 8$ & $4 \Phi 10$ & 20 & 2 & 1.86 & 65 & 586.1 & 107.1 \\
\hline C9 & $4 \Phi 10$ & 25 & 2 & 1.48 & 65 & 735.1 & 159.8 \\
\hline C10 & $4 \Phi 10$ & 30 & 2 & 1.24 & 65 & 862.8 & 204.9 \\
\hline $\mathrm{C} 11$ & $4 \Phi 10$ & 10 & 3 & 5.58 & 65 & 374.8 & 32.4 \\
\hline C12 & $4 \Phi 10$ & 15 & 3 & 3.72 & 65 & 506.8 & 79.1 \\
\hline C13 & $4 \Phi 10$ & 20 & 3 & 2.79 & 65 & 591.4 & 109.0 \\
\hline C14 & $4 \Phi 10$ & 25 & 3 & 2.23 & 65 & 742.6 & 162.4 \\
\hline $\mathrm{C} 15$ & $4 \Phi 10$ & 30 & 3 & 1.86 & 65 & 903 & 219.1 \\
\hline C16 & $4 \Phi 10$ & 10 & 1 & 1.86 & 90 & 429 & 51.6 \\
\hline C17 & $4 \Phi 10$ & 15 & 1 & 1.24 & 90 & 578.7 & 104.5 \\
\hline $\mathrm{C} 18$ & $4 \Phi 10$ & 20 & 1 & 0.93 & 90 & 743.4 & 162.7 \\
\hline C19 & $4 \Phi 10$ & 25 & 1 & 0.74 & 90 & 923.1 & 226.2 \\
\hline $\mathrm{C} 20$ & $4 \Phi 10$ & 30 & 1 & 0.62 & 90 & 1087.9 & 284.4 \\
\hline $\mathrm{C} 21$ & $4 \Phi 10$ & 10 & 2 & 3.72 & 90 & 457.2 & 61.6 \\
\hline $\mathrm{C} 22$ & $4 \Phi 10$ & 15 & 2 & 2.48 & 90 & 610.4 & 115.7 \\
\hline
\end{tabular}




\begin{tabular}{|c|c|c|c|c|c|c|c|}
\hline $\mathrm{C} 23$ & $4 \Phi 10$ & 20 & 2 & 1.86 & 90 & 780.6 & 175.8 \\
\hline C24 & $4 \Phi 10$ & 25 & 2 & 1.48 & 90 & 937.9 & 231.4 \\
\hline $\mathrm{C} 25$ & $4 \Phi 10$ & 30 & 2 & 1.24 & 90 & 1132.5 & 300.2 \\
\hline $\mathrm{C} 26$ & $4 \Phi 10$ & 10 & 3 & 5.58 & 90 & 496.7 & 75.5 \\
\hline $\mathrm{C} 27$ & $4 \Phi 10$ & 15 & 3 & 3.72 & 90 & 655.5 & 131.6 \\
\hline $\mathrm{C} 28$ & $4 \Phi 10$ & 20 & 3 & 2.79 & 90 & 810.5 & 186.4 \\
\hline $\mathrm{C} 29$ & $4 \Phi 10$ & 25 & 3 & 2.23 & 90 & 973.4 & 244.0 \\
\hline $\mathrm{C} 30$ & $4 \Phi 10$ & 30 & 3 & 1.86 & 90 & 1154.6 & 308.0 \\
\hline Co & $8 \Phi 16$ & \multicolumn{4}{|c|}{ Post-heated/non-jacketed (C7) } & 598 & 0.0 \\
\hline C31 & $8 \Phi 16$ & 10 & 1 & 26.8 & 65 & 758.2 & 28.7 \\
\hline $\mathrm{C} 32$ & $8 \Phi 16$ & 15 & 1 & 38.9 & 65 & 830.8 & 41.1 \\
\hline C33 & $8 \Phi 16$ & 20 & 1 & 57.9 & 65 & 944 & 60.3 \\
\hline C34 & $8 \Phi 16$ & 25 & 1 & 76.9 & 65 & 1058.1 & 79.6 \\
\hline C35 & $8 \Phi 16$ & 30 & 1 & 97.6 & 65 & 1181.6 & 100.6 \\
\hline C36 & $8 \Phi 16$ & 10 & 2 & 27.2 & 65 & 760.4 & 29.1 \\
\hline C37 & $8 \Phi 16$ & 15 & 2 & 41.9 & 65 & 848.8 & 44.1 \\
\hline C38 & $8 \Phi 16$ & 20 & 2 & 59.5 & 65 & 953.7 & 61.9 \\
\hline C39 & $8 \Phi 16$ & 25 & 2 & 80.8 & 65 & 1081 & 83.5 \\
\hline $\mathrm{C} 40$ & $8 \Phi 16$ & 30 & 2 & 104.6 & 65 & 1223.7 & 107.8 \\
\hline C41 & $8 \Phi 16$ & 10 & 3 & 39.6 & 65 & 834.7 & 41.7 \\
\hline C43 & $8 \Phi 16$ & 15 & 3 & 57.9 & 65 & 944.1 & 60.3 \\
\hline $\mathrm{C} 43$ & $8 \Phi 16$ & 20 & 3 & 75.5 & 65 & 1049.4 & 78.2 \\
\hline $\mathrm{C} 44$ & $8 \Phi 16$ & 25 & 3 & 95.5 & 65 & 1169.2 & 98.5 \\
\hline $\mathrm{C} 45$ & $8 \Phi 16$ & 30 & 3 & 114.0 & 65 & 1279.5 & 117.2 \\
\hline C46 & $8 \Phi 16$ & 10 & 1 & 42.1 & 90 & 850 & 44.3 \\
\hline C47 & $8 \Phi 16$ & 15 & 1 & 65.1 & 90 & 987.3 & 67.6 \\
\hline C48 & $8 \Phi 16$ & 20 & 1 & 89.5 & 90 & 1133.4 & 92.4 \\
\hline C49 & $8 \Phi 16$ & 25 & 1 & 119.0 & 90 & 1309.5 & 122.3 \\
\hline $\mathrm{C50}$ & $8 \Phi 16$ & 30 & 1 & 147.7 & 90 & 1481.5 & 151.5 \\
\hline C51 & $8 \Phi 16$ & 10 & 2 & 47.6 & 90 & 882.5 & 49.8 \\
\hline C52 & $8 \Phi 16$ & 15 & 2 & 70.9 & 90 & 1022.2 & 73.5 \\
\hline C53 & $8 \Phi 16$ & 20 & 2 & 95.6 & 90 & 1169.5 & 98.6 \\
\hline C54 & $8 \Phi 16$ & 25 & 2 & 121.1 & 90 & 1321.9 & 124.4 \\
\hline C55 & $8 \Phi 16$ & 30 & 2 & 151.1 & 90 & 1501.3 & 154.9 \\
\hline C56 & $8 \Phi 16$ & 10 & 3 & 56.5 & 90 & 935.8 & 58.9 \\
\hline C57 & $8 \Phi 16$ & 15 & 3 & 80.1 & 90 & 1077 & 82.9 \\
\hline C58 & $8 \Phi 16$ & 20 & 3 & 106.3 & 90 & 1233.8 & 109.5 \\
\hline C59 & $8 \Phi 16$ & 25 & 3 & 131.5 & 90 & 1384.5 & 135.1 \\
\hline C60 & $8 \Phi 16$ & 30 & 3 & 161.5 & 90 & 1563.8 & 165.5 \\
\hline
\end{tabular}

\section{Conclusion}

Based on the results of this paper obtained using both experimental and theoretical analysesfor columns subjected to fire, our conclusions can be drawn as follows: 
1. Based on theexperimental results,ferrocement confinement is aneffective technique to improve the strength of post-heated columns.

2. The ultimate load of post-heated columns reduced down to $45 \%$ after exposed to 300 ${ }^{\circ} \mathrm{C}$ for 3 hours. Also, the concrete becomes more porous with appeared a small cracks.

3. The strength of the post-heated columns repaired with ferrocement overlays was increased by $63 \%$ and $41 \%$ more than the strength of post-heated columnwith reference to reinforcement ratio.

4. Increasing the ferrocement thickness leads to ultimate load enhancement of repaired columns.

5. The ultimate load of post-heated column wrapped by ferrocement is significantly affected by increasing the thickness of the mortar

6. The reduced in the axial ultimate load of thepost-heated column with under-reinforced is more than that of over reinforced column.

7. The failure load of pre-heated columns decreased by $13 \%$ after heating, which proved that ferrocement coating is an effective heat insulator.

8. The ultimate loads of both the post-heated and pre-heated columns repaired with ferrocement overlaysare characterised with lower values compared to the original strength of un-heated columns.

9. The reduction in axial load of the post-heated over reinforced columns is less than that ofunder-reinforced columns.

10. Generally, the theoretical results obtained using both the finite element analysis and prediction formulaare in good agreement with the experimental values. The ANSYS program and predicted formula can be utilized to determine the effect of variables not studied experimentally.

\section{Acknowledgements}

The authors would like to express their thanks to the staff of the concrete research and material properties laboratory of the Faculty of Engineering, Fayoum University. In addition, the authors are grateful to Dr. Ahmed H. Mansi for his useful conversations and important suggestionswhich helped improving the quality of this manuscript.

\section{References}

[1] The American Concrete Institute, "Guide for design, construction \& repair of ferrocement," The American Concrete Institute, Michigan, USA, 1993.

[2] Abdullah and K. Takiguchi, "An investigation into the behavior and strength of reinforced concrete columns strengthened with ferrocement jackets," Cement and Concrete Composites, vol. 25, no. 2, pp. 233 - 242, 2003.

[3] A. Kaish, M. Jamil, S. Raman and M. Zain, "Axial behavior of ferrocement confined cylindrical concrete specimens with different sizes," Construction and Building Materials, vol. 78, pp. 50-59, 2015.

[4] A. Kaish, M. Alam, M. Jamil, M. Zain and M. Wahed, "Improved ferrocement jacketing for restrengthening of square RC short column," Construction and Building Materials, vol. 36, pp. 228-237, 2012.

[5] S. Mourad and M. Shannag, "Repair and strengthening of reinforced concrete square columns using ferrocement jackets," Cement and concrete composites, vol. 34, no. 2, pp. 288-294, 2012. 
[6] A. Al-Sibahy, "Behaviour of Reinforced Concrete Columns Strengthened with Ferrocement under Compression Conditions: Experimental Approach," World Journal of Engineering and Technology, vol. 4, no. 4, pp. 608-622, 2016.

[7] M. Salih and C. Arunkumar, "Strengthening of reinforced concrete column using Jacketing Technique," in International Conference on Engineering Innovations and Solutions, 35-38, 2016.

[8] J. Malhotra, "Behaviour of RCC columns confined with ferrocement," Thapar University, 2013.

[9] S. Sirimontree, B. Witchayangkoon and K. Lertpocasombut, "Strengthening of Reinforced Concrete Column via Ferrocement Jacketing," American Transactions on Engineering and Applied Sciences, vol. 4, no. 1, pp. 39-47, 2015.

[10] V. Shinde and J. Bhusari, "Response Of Ferrocement Confinement On Behavior Of Concrete Short Column," IOSR Journal of Mechanical and Civil Engineering (IOSRJMCE), p. 24-27, Shinde.

[11] M. Soman and M. Veena, "Repair and rehabilitation of RC short square columns using improved ferrocement jacketing," in International Journal of Earth Sciences and Engineering, 2015.

[12] L. Abdel-Hafez, A. Abouelezz and A. Hassan, "Behavior of RC columns retrofitted with CFRP exposed to fire under axial load," HBRC Journal, vol. 11, no. 1, pp. 68-81, 2015.

[13] J. Rodrigues, L. Laím and A. Correia, "Behaviour of fiber reinforced concrete columns in fire," Composite Structures, vol. 92, no. 5, pp. 1263-1268, 2010.

[14] K. K. Venkatesh, A. B. Luke and F. G. Mark, "Experimental evaluation of the fire behaviour of insulated fibre-reinforced-polymer-strengthened reinforced concrete columns," Fire Safety Journal, vol. 41, no. 7, pp. 547 - 557, 2006.

[15] D. Cree, E. Chowdhury, M. Green, L. Bisby and N. Bénichou, "Performance in fire of FRP-strengthened and insulated reinforced concrete columns," Fire Safety Journal, vol. 54, pp. 86 - 95, 2012.

[16] L. Bisby, J. Chen, S. Li, T. Stratford, N. Cueva and K. Crossling, "Strengthening firedamaged concrete by confinement with fibre-reinforced polymer wraps," Engineering Structures, vol. 33, no. 12, pp. 3381 - 3391, 2011.

[17] M. Yaqub and C. Bailey, "Repair of fire damaged circular reinforced concrete columns with FRP composites," Construction and Building Materials, vol. 25, no. 1, pp. 359 - 370, 2011.

[18] E. Chowdhury, "Behaviour of fibre reinforced polymer confined reinforced concrete columns under fire condition," Queen's University, Ontario, Canada, 2009.

[19] A. Parvin and D. Brighton, "FRP composites strengthening of concrete columns under various loading conditions," Polymers, vol. 6, no. 4, pp. 1040-1056, 2014.

[20] Y. Al-Kamaki, R. Al-Mahaidi and I. Bennetts, "Experimental and numerical study of the behaviour of heat-damaged RC circular columns confined with CFRP fabric," Composite Structures, vol. 133, p. 679-690, 2015.

[21] H. Z. El-Karmoty, "Thermal protection of reinforced concrete columns strengthened by GFRP laminates (experimental and theoretical study)," HBRC Journal, vol. 8, no. 2, pp. $115-122,2012$.

[22] Z. C. Tetta and A. B. Dionysios, "TRM vs FRP jacketing in shear strengthening of concrete members subjected to high temperatures," Composites Part B: Engineering, vol. 106, pp. 190 - 205, 2016. 
[23] M. Yaqub, C. Bailey and P. Nedwell, "Axial capacity of post-heated square columns wrapped with FRP composites," Cement and Concrete Composites, vol. 33, no. 6, pp. 694 - 701, 2011.

[24] M. Yaqub and C. Bailey, "Seismic performance of shear critical post-heated reinforced concrete square columns wrapped with FRP composites," Construction and Building Materials, vol. 34, pp. 457 - 469, 2012.

[25] C. Bailey and M. Yaqub, "Seismic strengthening of shear critical post-heated circular concrete columns wrapped with FRP composite jackets," Composite Structures, vol. 94, no. 3, pp. 851-864, 2012.

[26] M. Yaqub, C. Bailey, P. Nedwell, Q. Khan and I. Javed, "Strength and stiffness of post-heated columns repaired with ferrocement and fibre reinforced polymer jackets," Composites Part B: Engineering, vol. 44, no. 1, pp. 200 - 211, 2013.

[27] ANSYS, "ANSYS User's Manual and Help Revision 13," ANSYS Inc., PA, USA, 2010 . 